\title{
Movimentos Sociais de Crianças / Children's Social Movements
}

https://doi.org/10.21814/uminho.ed.36.44

\section{Marta Martínez Muñoz}

Socióloga, y Evaluadora. Consultora, docente y investigadora en España y en América Latina 



\section{Movimentos Sociais de Crianças}

Os movimentos sociais são associações mais ou menos estruturadas de pessoas que estão unidas por interesses comuns e que desejam a mudança social por meio de diferentes mecanismos de articulação e protesto social. Organizam-se em torno de objetivos comuns e tentam influenciar outros indivíduos, grupos sociais e a política em geral. Até ao início do século $\mathrm{XXI}$, a pesquisa científica raramente se focava em identificar se as crianças - entendidas no sentido da Convenção das Nações Unidas sobre os Direitos da Criança como pessoas menores de 18 anos - podiam ser agentes dos movimentos sociais e sobre questões relativas à forma como atuavam e como deviam ser percebidas. Os Estudos da Infância foram abrindo, gradualmente, uma perspetiva que entende as crianças como (potenciais) atores dos movimentos sociais, considerando abordagens que as consideram como construtoras da realidade social. Em consonância com outros movimentos de grupos sociais excluídos, afirmam ser sujeitos com base na dignidade e no respeito pela vida humana. Existem várias expressões no que diz respeito aos movimentos sociais, desde as supra regionais e mesmo organizadas internacionalmente, até as iniciativas informais e restritas localmente.

Quando olhamos para os movimentos de crianças, nem sempre se faz uma distinção entre aqueles que atuam em prol dos direitos da criança e os movimentos liderados por elas. Na história, as crianças quase nunca foram consideradas como capazes de atuar; a sua participação em movimentos sociais incorpora pessoas de todas as idades e principalmente movimentos que dependem da população infantil. Entre estes últimos, muitas vezes é feita uma distinção entre grupos informais, em vez de grupos espontâneos, e movimentos organizados nos quais as crianças são atores determinantes e atuam como defensores dos direitos humanos das crianças em particular, e dos direitos humanos em geral. Os movimentos sociais de crianças costumam ser fruto de projetos pedagógicos e sociais voltados para a defesa e promoção de seus direitos. Em geral, a participação de crianças nesses movimentos continua a ser um campo das ciências sociais pouco estudado. Isso deve-se ao facto de a infância ser vista como um espaço protegido e universalizado, negando assim as suas múltiplas localizações sociais. Os poucos estudos existentes sobre a criança como participante de movimentos 
sociais mostram, entretanto, que a realidade infantil esbarra nessa imagem hegemónica da infância.

Os movimentos sociais organizados e liderados por crianças surgem por diversos motivos e assumem diferentes formas e contextos. Isso requer levar em conta um conceito fluido de movimentos sociais que inclui grupos informais, principalmente locais, bem como associações organizadas mais sólidas, muitas vezes atuantes ao nível nacional ou mesmo internacional e defendendo diferentes temas, como os movimentos de crianças trabalhadoras, movimentos dentro e contra a escola, grupos de autoajuda de crianças deslocadas e excluídas e, de maneira mais geral, as chamadas culturas ou comunidades infantis que às vezes surgem no contexto das novas formas de comunicação mediatizadas e, mais recentemente, os movimentos de defesa do meio ambiente.

Os movimentos sociais de crianças geralmente precisam do acompanhamento de pessoas adultas e organizações por diversos motivos. A renovação geracional dos seus líderes a cada quatro a cinco anos, e os representantes emergentes precisam ser motivados e treinados. Além disso, por serem "menores" no sentido jurídico, os participantes dos movimentos precisam que os adultos assinem acordos contratuais com governos, organizações não-governamentais ou organizações internacionais ou sejam formalmente registados a nível nacional. Por outro lado, geralmente há uma falta de reconhecimento social que deve ser fortalecido e compensado por adultos aliados e não adultos.

Como exemplos com mais história de vida, encontramos na América Latina os movimentos de NNATs (meninos, meninas e adolescentes trabalhadores) presentes em vários países (no Peru existe o MANTHOC [1976] há mais de 40 anos) articulados no movimento hemisférico MOLACNATS e, até ao momento, eles são uma das manifestações mais evidentes de agência e do papel da infância; na África, existe o Movimento Africano de Crianças e Jovens Trabalhadores (MAEJT) e na Ásia eles estão frequentemente associados às atividades de apoio de organizações não-governamentais (ONG) nacionais e internacionais, especialmente com seus programas com crianças que vivem e/ou trabalham nas ruas de grandes cidades, especialmente com a organização Concerned for Working Children, localizada na Índia, e a ONG Knowing Children, com sede na Tailândia.

Outras experiências podem ser encontradas em movimentos estudantis que procuram desafiar o modelo educacional das escolas para torná-las 
mais atraentes e, em última instância, mais aplicáveis às suas vidas. Nesse sentido, a "mudança escolar liderada por alunos" é um movimento crescente em diferentes estados dos Estados Unidos. Existem também outros jovens que falam a favor de uma abordagem mais radical de "desescolarização" e "libertação" do controlo adulto. Em alguns países, como Chile ou Peru, as crianças formam movimentos por mudanças nas políticas públicas de educação e exigindo acesso gratuito a escolas de melhor qualidade, incluindo escolas administradas pelas próprias crianças e respeitando a sua experiência de vida e suas necessidades diárias.

\section{Children's Social Movements}

Social movements are more or less structured associations of people who are linked by common interests and who want to achieve social change through different means of expression and social protest. They organize around common goals, try to influence other individuals, social groups, and politics in general. Until the beginning of the 21st century, scientific research has very rarely focused on identifying whether children - understood in the sense of the United Nations Convention on the Rights of the Child as persons under 18 years of age - can be agents of the social movements and involved in issues relating to how they act and how they should be perceived. Childhood studies have gradually opened up a perspective that understands children as (potential) actors in social movements, applying approaches that perceive them as co-constructors of social reality. In accordance with other movements of excluded social groups, they claim to be subjects on the basis of dignity and respect for human life. There are different manifestations, from the supra-regional and even the internationally organized, to informal and restricted initiatives at the local level.

When we observe children's social movements, a distinction is not always made between those acting in favour of children's rights and movements led by children themselves. In history, children have almost never been considered capable of acting; their participation in social movements incorporates people of all ages and especially movements that rely on the child population. Among the latter, a distinction is often made between informal, rather spontaneous groups, and organized movements. In the latter children are determining actors and act as defenders of the human rights of children in particular, and of human rights as a whole. The children's social movements are usually the result of pedagogical and social projects oriented to the defence and promotion of their rights. In general, the 
participation of children in these movements remains a field of social science that is still under-researched. This has to do with the fact that childhood is seen as a protected and universalized space, thus denying its multiple social locations. The few existing studies on children as participants in social movements show, however, that the reality of children collides with this hegemonic image of childhood.

Social movements organized and led by children arise for various reasons and in different forms and contexts. This requires taking into account a fluid concept of social movements that includes informal groups, mostly local, as well as more solid organized associations, often active at the national or even international level and defending different themes. These include matters such as movements of working children, movements in and against school, self-help groups of displaced and excluded children and, more generally, the so-called child cultures or communities that sometimes emerge in the context of the new media. More recently, the movements for the defence of the environment have taken place.

The children's social movements often need the accompaniment of adult people and organizations for different reasons. The generational renewal of its leaders takes place every four to five years, and emerging representatives need to be motivated and trained. Furthermore, because they are "minors" in the legal sense, the participants of the movements need adults to sign contractual agreements with governments, non-governmental organizations or international organizations or to be formally listed in national registries. On the other hand, there is usually a lack of social recognition that must be strengthened and compensated by adult allies and non-adultists.

Considering more historical examples in Latin America, we find the movements of NNATs (working boys, girls and adolescents) in several countries (In Peru there is MANTHOC [1976], effective for more than 40 years) and in the hemispheric movement MOLACNATS. To date, they are some of the most evident manifestations of agency and the role of childhood. In Africa, there is the African Movement of Children and Young Workers (MAEJT) and in Asia they are often closely associated with the support activities of national and international non-governmental organizations (NGOs). The special focus of their programmes is on the children living and/or working on the streets of big cities, especially with the Concerned for Working Children organization, located in India, and the NGO Knowing Children, based in Thailand. 
Other examples are found in student movements that seek to challenge the educational model of schools to make them more attractive, and ultimately more applicable to their lives. In this sense, "student-led school change" is a growing movement in different states of the United States of America. There are also other young people who speak out in favour of a more radical approach to "unschooling" and "liberation" from adult control. In some countries, such as Chile or Peru, children are forming movements for change in public education policies and demanding free access to better quality schools, including schools run by the children themselves, respecting their life experience and daily needs.

\section{Referências / References}

Cussiánovich, A. \& Méndez, D. (2008). Movimientos Sociales de NATs en América Latina: Análisis Histórico y Balance Político en los Últimos Treinta Años. Lima: Ifejant.

Liebel, M. (2006). Los movimientos de los niños y niñas trabajadores. Un enfoque desde la sociología. Política y Sociedad, 43(1), 105-123.

Martínez Muñoz, M. \& Cabrerizo Sanz, L. (2015). Guía para la Evaluación. Herramienta Prota-Estela. Lima: Ed. Save the Children International \& Enclave de Evaluación.

Ungar, M. (2005). Handbook for Working with Children and Youth: Pathways to Resilience across Cultures and Contexts. Thousand Oaks, CA: SAGE. 